\title{
Protest and the Politics of Space and Place, 1789-1848
}

Review Number: 1987

Publish date: Thursday, 8 September, 2016

Author: Katrina Navickas

ISBN: 9780719097058

Date of Publication: 2015

Price: $£ 71.48$

Pages: 352pp.

Publisher: Manchester University Press

Publisher url: http://www.manchesteruniversitypress.co.uk/9780719097058/

Place of Publication: Manchester

Reviewer: Mike Sanders

'Space and place are central to the strategies and meaning of protest' (p. xi) reads the opening sentence of Katrina Navickas's latest study, Protest and the Politics of Space and Place 1789-1848. Written, in part, as a response to the 'spatial turn' in History, Navickas makes a cogent and persuasive argument for attending to the importance of the particularities of 'place' rather than the abstractions of 'space' in historical studies. Her study is divided into three parts; 'Spaces of exclusion, 1789-1830', 'Spaces of the body politic in the 1830s and 1840s' and 'Region, neighbourhood and the meaning of place'. Each part contains three chapters and one 'vignette', with an introduction and conclusion book-ending the volume.

The 'Introduction' offers an overview of both the theoretical underpinnings of the study and its relationship to the current historiographical debate. Navickas begins by observing the shifting definitions, meanings and even locations of 'public', 'civic' and 'private' space in the period covered by her study (pp. 1-3). She also offers her work as a narrative of the ongoing closing down of public spaces as sites of protest between 1789-1848, and traces both the legislative measures used by elite groups in pursuit of closure and the tactical and strategic responses of the working classes (pp. 5-9). Navickas is refreshingly clear as to the actors and stakes involved: 'Contests over the body politic and its spaces were contests between classes' (p. 9). She is equally clear as regards her own theoretical affiliations, arguing that historians have tended to confuse 'space' and 'place' and making clear own preference for notions of place as understood by cultural geographers (pp. 14-16).

The work's first chapter, 'Spaces of exclusion and intrusion in the 1790s', focuses on loyalist attempts to control civic and public spaces in the 1790s. Through detailed case-studies of Manchester and Sheffield, Navickas not only examines the ways in which local elites organised carefully choreographed and highly ritualised public displays of loyalty, but also traces their systematic attempts to exclude radicals and their ideas from the civic body politic. Her 'thick' descriptions of the loyalist violence and intimidation directed against key figures in the Manchester Constitutional Society and the Sheffield Society for Constitutional Information (pp. 38-50), are not only chilling in their detail, but are redolent of E. P. Thompson's classic 'The Making of the English Working Class' in the way in which local detail is tellingly deployed both to illustrate and add nuance to a more general argument. The chapter ends with a recognition of the relative success of loyalism, although 'Loyalist hegemony' (p. 50) seems too strong a term, given Navickas's own 
insistence on the role played by repression in driving radicalism from the public sphere - 'Fear of spies and arrest and Church-and-King violence had a psychological impact upon radicals, constraining their room for manoueuvre' (p. 50).

Radicalism's response to this predicament, the organising of mass public meetings (as a way of insisting on their constitutional and legal status), provides the subject matter for the second chapter - 'Defending the liberty to meet, 1795-1819'. This chapter opens with a detailed discussion of the Government's repeated attempts at defining a legitimate public meeting which began with the Seditious Meetings Act of 1795. It also explores the various ways in which new forms of radical organisation (such as the Hampden clubs of North-West England) sought to remain within those restrictions whilst simultaneously seeking to extend their freedom of movement by exploiting legal loopholes. The chapter continues by surveying the types of indoor spaces - such as pubs, union rooms and dissenting chapels - which were available to radicals, before moving on to consider the kinds of outdoor spaces that could be used for larger, public meetings - the mass platform. These latter spaces are pithily characterised by Navickas as 'spaces of making do' (p. 74). She argues that such sites generally occupied liminal spaces (wasteland, the edges of jurisdictional areas, 'unimproved' land on the outskirts of town), and that it was their very liminality, their non-incorporation in civic-patriotic rituals, which made it possible for radicals to use such sites in the first instance. In addition, Navickas argues that through 'repeated use, [these sites] became what Pierre Nora termed "lieux de memoire", sites layered with popular memory, moulded and manipulated by the political activists who stood on the stage and later memorialised the sites in speeches and narratives for their own political ends' (p. 66).

Chapter three, 'Peterloo and the changing definition of seditious assembly', maintains the focus on government attempts to constrain radicalism though the passage of restrictive legislation. Navickas draws attention to the way in which Lord Sidmouth introduced a subjective test for determining the legality (or otherwise) of a public meeting, whereby an 'impression of fear and terror ... became the grounds for suppression rather than actual disorder' (p. 86). Thus, not only the manner, but also the interpretation, of the conduct of radical crowds became a matter of some importance. Navickas suggests that radicals drew from practices associated with the funeral cultures of both Methodism and the Trades in order to underscore the respectable and pacific nature of their own processions. However, the passage of the Seditious Meetings Act in 1819 which prohibited the use of 'flags, banners and other emblems' (p. 98), made it all but impossible for radicals to organise mass meetings and, as a result, radical culture was forced indoors.

Chapter four, 'Embodied spaces and violent protest', offers a compelling analysis of certain forms of labour resistance to the onset of proletarianisation. Navickas argues for an understanding of Luddism, Swing and the 'Plug strikes' as 'defences by skilled workers against threats to a collective body, defined by skill, custom and place' (p. 150). She also offers an intriguing reading of machine-breaking and threatening letters as an attempt to inflict 'disembodied pain upon their targets' (p. 131). This insistence on interpreting the actions of workers within a wider cultural framework (which includes but is not confined to the 'economic') is one of the strengths of the chapter. However, the question arises as to how far these forms of protest are related to either space or place? For example, the triad of 'skill, custom and place' suggests an interrelationship between its constituent parts which the chapter never quite pins down. Similarly, 'disembodied pain' strikes me as a symbolic rather than a spatial concept. At such times, the evidence assembled with evident care by Navickas seems to me to resist, or at the very least problematise, the theoretical framework within which it is being analysed. Elsewhere, it should be noted, the focus on place does yield impressive results, exemplified in this chapter by a detailed demonstration of the ways in which the the imposition of the New Poor Law and the new police forces elicited a markedly different response in the West Riding than it did in the East or North Ridings (pp. 135-48).

The importance of local differences also forms the substance of chapter five, 'Contesting new administrative geographies in the 1830s and 1840s'. This chapter not only demonstrates the importance of 'local' politics in the early-mid-19th century, but also the wide variety of formal institutions within which it was played out. In an illuminating analysis, Navickas explores the shifting class and political alliances produced by struggles to control vestries, poor law administration, improvement, highway and police commissions, as well as local 
councils. In addition, she argues that the struggles over the new police commissions 'became a training ground for the political talents and ideas of future Chartists' (p. 165). Once again, the question of the specific weight to be accorded to 'place' arises. For example, the chapter certainly demonstrates that in certain locales the new poor law was resisted by administrative means, but it is difficult to see how the essentially metaphorical notion of 'administrative geography' adds to our understanding of this process.

Chapter six, 'Constructing new spaces', examines the efforts of Owenite Socialists, Chartists and Trades Unionists to secure (sometimes by building) their own, autonomous indoor meeting spaces. Navickas surveys the chapels, association rooms and working-men's halls as well as more impressive showcase buildings such as the Carpenters' Hall and the Owenite Hall of Science in Manchester. The latter buildings both had a capacity in the thousands and constituted important physical statements of working-class power. The chapter details the various uses to which these buildings were put - political, educational and social and offers a short section on analogous middle class sites, such as the Free Trade Hall in Manchester. It ends with a discussion of the financial and legal problems associated with owning and renting property.

The final three chapters shift focus away from 'space' towards a concentration on the 'meaning of place' (p. 224). In chapter seven, 'The liberty of the landscape', Navickas considers the various meanings of pedestrianism, highlighting the political significances which differentiate a walk in the park from a ramble over moorland, and exploring the remarkable distances covered on foot by Chartist missionaries. In addition, the chapter explores the ways in which the Chartist camp and monster meetings offered 'a mirror of the civic processions to which they formed an alternative, stratified by political leadership, geography and gender' ( $\mathrm{p}$. 244). Chapter eight, 'Rural resistance', begins by noting the difficulty of assimilating rural resistance to the 'progression model that assumes greater organisation and bureaucratisation of political movements by the nineteenth century' (p. 251). In a wide-ranging chapter which highlights the significance and the complexity of local conditions in shaping forms of rural resistance, Navickas examines the practices of animal and tree maiming, the persistence of resistance to enclosure into the 1830s and the struggle over footpaths and rights of access. The highlights of this chapter are the combined accounts of rural Luddism and the specificities of 'Northern swing' - two episodes in the history of labouring-class resistance which are often overlooked (pp. 264-76).

Chapter nine, 'Making Moscows, 1839-48', begins by emphasising the political contingencies which were in play throughout the period of Chartist agitation. Navickas reviews the existing scholarship which demonstrates not only that the State's response varied considerably depending on who was occupying the position of Home Secretary, but also that tensions between magistrates and military commanders added an additional layer of contingency at the local level. She then builds impressively on these foundations by demonstrating that local terrains also played an important role in shaping the nature of local confrontations between people and State. For example, Navickas shows how the steepness of the hills in towns such as Bradford, Colne and Oldham, rendered cavalry troops far less effective, whilst the narrow alleyways enabled the populace to 'launch crossfire as the military attempted to ascend' (p. 286). Yet there is a sense in which even this very clear demonstration of the importance of local place simultaneously demonstrates the limits of its influence. For in all of the confrontations between Chartism and the State the Chartists possessed superior knowledge of the local terrain, yet in every case the authorities quickly re-established 'order'.

Navickas's conclusion stresses the importance of the local and the complexity of the laboring class response to the nascent industrial capitalist order. Indeed, it might be argued that the hypothesis informing this study is, complex because local. As Navickas writes:

radical movements throughout this period were popular because they were locally based and loosely federated rather than homogeneous. The goals of parliamentary reform, universal suffrage and workers' rights were simultaneously national and translated into local circumstances by a diverse range of political and social groups. The two co-existed and indeed interacted with each other, rather than the local being transmuted to a more generalist national 
An intriguing feature of this passage is that the terms 'national' and 'local' could be transposed with no diminution of insight, so that the sentence could read: 'The goals ... were simultaneously local and translated into national circumstances by a diverse range of political and social groups'. This suggests that Navickas has identified a crucial dialectic for the politics of her chosen period. The articulations (in the dual sense of joining and voicing) of space and place at both the national and the local level are indeed important features of the strategies and meanings of protest.

As noted earlier, Navickas punctuates the three parts of her study with three 'vignettes'. These are a form of micro-chapter which resemble the series of 'Chartist lives' variously used by Malcolm Chase in his Chartism: A New History (1), to illustrate, complement or amplify the concerns of the chapter to which they were appended. They are intended to serve a similar function here, but their effectiveness is more uneven. The first two vignettes, 'Radical locales' and 'Processions', demonstrate the value of this approach. The first offers a concentrated history of the sustained radical commitment of four areas of North Manchester (Ancoats, New Cross, Angel Meadows and St George's). Navickas quite literally maps radical activity across these districts to show how these communities sustained radical activity across generations. The second vignette is even more fascinating. It maps the routes of political processions in Manchester and Leeds and shows how Loyalist and radical marches followed totally distinct itineraries in the former, and identical ones in the latter. The vignette ends with a fascinating, if under-developed, point regarding the ending of parades celebrating the Queen's birthday in Manchester in 1840. The final vignette, 'New horizons in America', comes as something of an anti-climax in comparison. Largely a litany of radical disappointments with, or in, the United States of America, this vignette lacks the sharpness of its two predecessors.

Protest and the Politics of Space and Place 1789-1848 connects disparate phases of the history of radicalism in ways which bring out continuities which may otherwise remain obscured. For example, as someone interested in Chartism, I found Navickas's accounts of the spatial strategies of the 'Jacobin' radicals provided a helpful context for understanding the ways in which Chartists sought to occupy space. Similarly, her argument that struggles over the new police commission provided a training ground for many soon-to-be Chartists opens up a new dimension of Chartist history. However, perhaps inevitably with such a flexible notion, there is a problem of slippage from actual into metaphorical uses of 'space' e.g. 'The law itself was a contested space' (p. 45) and the notion of 'administrative geographies' (chapter five). Likewise, while I think Navickas is absolutely correct to privilege place over space as an analytical category, there is a sense in which 'place' remains under-theorised throughout the study. In particular, Navickas frequently (and correctly) invokes the notion of 'narrative' when discussing place. However, narrative necessarily introduces a temporal dimension which problematises our understanding of the modes of agency involved - action does indeed occur in space, but it also occurs in space at a particular time. Here, perhaps, Bakhtin's concept of the 'chronotope' (a culturally specific fusion of time and place) might provide a useful way forward.

Similarly, there is a problem at times between the competing demands of a history focused on space/place and a diachronic/developmental model. For example, in the second chapter, the discussion of the March of the Blanketeers is largely concerned with tracing the Government's response (in the forms of further repressive legislation) and the subsequent challenges this generated for the radical movement. What is missing here is a consideration of the way in which the Blanketeers politicised space in a markedly different way from the radicals of the 1790s. The March of the Blanketeers represented an attempt to claim 'national' as opposed to 'local' space for radical politics. Furthermore, unlike a mass meeting, it was characterised by a more fluid, less predictable, movement of bodies in and through space - and this was surely one of the features which most alarmed the authorities. In this latter aspect, the Blanketeers resembled the Luddites (and, it might be argued, anticipated the 'Plug' strikers of 1842), and it is perhaps surprising that the study does not consider these parallels.

One of the undoubted strengths of this study is its attempt to articulate the multiple relationships between the local and the national. Chapters one, two, three and five, which concentrate on local responses to national 
legislation, and see national legislation as a response to various local circumstances, provides one way of mapping this relationship. Chapters four, seven, eight and nine have a greater focus on 'local' circumstances and, to some extent, also invoke the notion of the 'region' as an intermediate site between the locale and the state. The former method allows for a tidier narrative, the latter captures more of the complex messiness of history as lived experience. My sense is that it is probably impossible for a single historian to achieve the necessary synthesis between these two approaches and, therefore, that a possible way forward might be to think in terms of a method of collaborative scholarship in which a series of local studies is followed by a more generalized study which abstracts from and theorises from those same local studies. If such a venture proves possible, it will owe a great deal to the pioneering research of Navickas in this volume.

\section{Notes}

1. Malcolm Chase, Chartism: A New History (Manchester, 2007).Back to (1)

\section{Other reviews:}

Protest History

http://protesthistory.org.uk/ [2]

Source URL:https://reviews.history.ac.uk/review/1987

\section{Links}

[1] https://reviews.history.ac.uk/item/176609 [2] http://protesthistory.org.uk/ 